\title{
Recenzja książki ks. prof. zw. dr. hab. Jana Kantego Pytla ,Świat cały rozgorzal i w ogniach stoi. Refleksje z wczoraj na jutro", Pallottinum 2016
}

Książka zawiera 21 krótkich rozważań. To liczba symboliczna. Trójka i siódemka - symbole doskonałości - przemnożone przez siebie dają liczbę 21, czyli najwyższą doskonałość. Rozważania te są bardziej rozwiniętą formą ,przypowiastek filozoficznych". Autor wychodzi od przedstawienia pewnego, bardzo charakterystycznego dla obecnych czasów epizodu i rozwija go w oparciu o przebogatą wiedzę z trzech dziedzin: teologii, historii i literatury. Dorzuca też scenki z doświadczenia życiowego, które służą jako obrazowe przykłady do omawianej tezy.

Tematy rozważań dotyczą głownie zagadnień egzystencjalnych, pytań od zawsze nurtujących człowieka: o istnienie Boga, dlaczego w świecie spotyka nas zło i cierpienie, czy szatan jest czy go nie ma, jak poszukiwać prawdy, czym jest wolność chrześcijańska itp. Jednak spojrzenie na te problemy rzucone jest z nowej ,prowokacyjnej” perspektywy, co zaznacza się już w tytułach kolejnych rozdziałów: Błaga Cięo to Madonna ateistów, Ciocia mówiła, że nie ma diabła, Kłamcie, kłamcie, zawsze coś z tego zostanie, Jedzta, co chceta, Księże proboszczu, mnie zbawienie nie interesuje, itp.

Katechezy te świadczą o głębokiej erudycji Autora, ale napisane są tak lekko i tak przystępnie, że mogą być rozumiane przez każdego odbiorcę. A przede wszystkim nie są nudne. Jest w nich subtelna ironia, poczucie humoru i paradoksu. Myśl czytelnika, a może bardziej słuchacza, gładko przesuwa się po kolejnych akapitach, nie tracąc ciągłości rozważań i zainteresowania tematem. Autor dzieli się swoją ogromną wiedzą i życiowym doświadczeniem, a czyni to w celu dydaktycznym i moralizatorskim. Bo przede wszystkim jest księdzem, homilistą, który zajmuje się wygłaszaniem kazań i interpretacją tekstów biblijnych, żarliwie z głębi serca pragnie nauczać, głosić i wyjaśniać Słowo Boże. „Głosić je nie tylko - jak mówi św. Paweł - „w porę i nie w porę”, ale szukać też najciekawszych, najbogatszych form przekazu.

Książkę czyta się zatem z prawdziwą przyjemnością i chętnie, a zawarta w niej refleksja Autora rozświetla również i nasze myślenie, stając się drogowskazem na życiowych ścieżkach.

ks. prof. dr hab. Bogdan Poniży

Uniwersytet im. Adama Mickiewicza w Poznaniu 